\title{
Differences between Social Science Teachers and Physics Teachers about Beliefs of Competences Model in Mexico
}

\author{
Mario H. Ramírez Díaz ${ }^{1, *}$, Luís Antonio García Trujillo², David A. Chávez-Campos² \\ ${ }^{1}$ Graduate Department of Physical Education, Applied Research Center for Advanced Science and Technology, National Polytechnic \\ Institute, Mexico \\ ${ }^{2}$ Faculty of Physical and Mathematical Sciences, Autonomous University of Coahuila, Mexico
}

Copyright $\odot 2016$ by authors, all rights reserved. Authors agree that this article remains permanently open access under the terms of the Creative Commons Attribution License 4.0 International License

\begin{abstract}
This paper shows the results of a diagnostic research that evaluates the perception of teaching competencies by physics teachers, in universities and high schools that have experienced curricular change of the mode of competences-based education (EBC). The research was conducted in both physics teachers in high school and college level nationally and compared with the results obtained with social science teachers in the state of Tabasco. The main purpose is to account for the way in which teachers accept, resist, or refuse to change their teaching model as a result of the changes experienced by traditional curriculum to competences-based model, whose main features are that the contents are linked to the productive and social sector; subjects are supported with the use of ICT; to students to acquire skills, and attitudes on the use and transfer of knowledge and thus learning to learn. The results from both disciplines teachers show some common aspects, however, there are also important differences in the appreciation from both groups over the success of this model.
\end{abstract}

Keywords Competences Model, Physics Education, Curriculum Design

\section{Introduction}

In recent years' education has been incorporated by the competency model to higher education institutions, both in Mexico, and internationally. In this sense, we have made efforts to study the specific competency to be developed in different university programs for various instances; an example of this is the studies conducted by the Tuning Project, both in Europe and in Latin America. In particular, the Tuning Latin America project studied, in chapter 4.6, degree programs in physics in 12 countries including Mexico [1].

At other levels, the progress of changes in plans and curricula has been studied successfully from the introduction of competency model, in the case of the physics programs at secondary level; it is interesting the experiences of the Spanish and Chilean model $[2,6]$.

The work around learning physics by this model is not new, in fact there are efforts by the same Tuning Project [3] where they make suggestions for the design and construction of programs based physical competences model. In the case of teacher training, there are also efforts in the area of physics; particularly, the training of teachers at the National Polytechnic Institute of Mexico (IPN) is related to the institutional educational competences model that follows from the 2000 [4] and have implemented training courses specifically aimed to teachers of physics for understanding and implementation of the model in their courses and Olvera \& Ramirez [5]. Yet, despite the efforts mentioned, the perception of physics teachers about the competency model is still bad, starting with a general ignorance of what is the model by itself, and this has been evident in various academic meetings and area meetings of the AAPT, ICPE and WCPE $[8,9,10]$.

On the other hand, the effect and perception of the competency model has been studied in other disciplines, such as several branches of social sciences, particularly in a study made in Tabasco, Mexico, which is described in detail in the next section [7]. The survey applied to social sciences teachers made us to ask the next questions: What is the perception about the competency model in Mexican physics teachers? , Is the perception about the competency model of teachers in other disciplines different to physics teachers? If it is, what are the differences and similarities between social science teachers and the physics teachers?

The previous questions are important, this because in Mexico, the competency model has been established in almost all universities programs and they are obligate to implement it.

A work team was formed to answer these questions, which was composed by professors in physics programs of engineering careers, (undergraduate level) and professors in physics education graduate, who realize the work done by 
the social sciences researches and decided to expand this work and compliment it in physics area. The hypotheses generated by the questions led the group to believe that despite the competency model is similarly applied in different disciplines and university programs; there are differences in the perception of social sciences professors and physics professors, this is due to professional profile of teachers, experience and disciplines itself. An example of this, could be represented by the fact that teachers of social sciences (in general) are professionals who teach courses at the university as a sideline to their profession, which they exercise regularly, while physics teachers are exclusively dedicated to the teaching of courses in the university and undertake research in the area of physics but within the same university environment [11].

In this paper we show a comparative study about the perception on competences model between Social Science and Physics teachers, showing the thought about success or fail the model, the role of teacher and a general evaluation of the model.

\section{Methodology}

As mentioned in the previous section, the interest in making a comparative study comes to resume the job done with social science teachers in Tabasco. However, the research group with physics professors stood at Mexico City and it did not have a direct contact with the sample of social sciences professors. On the other hand, the physics professors profile is mostly physicists (some with graduate degrees in physics), who are teaching courses in physics or physical engineering programs (Some universities were: National Autonomous University of Mexico, Polytechnic Institute National, Technological Institute of Higher Studies in Monterey, Autonomous University of Nuevo Leon, Gulf Polytechnic University, Autonomous University of Baja California, Coahuila Autonomous University, Technological Institute of Comalcalco, Media Institute of Higher Education of the Federal District). This makes the present study is a qualitative research-intensive small-scale type, without rules of procedure (since the variables are not susceptible to quantitative measurement) and recursive design [12].

The methodology used to carry out the diagnosis and evaluation of teaching skills in higher education institutions which have implemented Tabasco and operate the competences-based educational model (EBC) is a typical descriptive - exploratory mixed cut, which consists of the following phases: The first phase is the review of governing documents and policies for IES on competences model, the first stage allowed to extract relevant and updated information about the contents that may be incorporated in the analysis and evaluation of this phase. A second stage involved the determination of a representative sample of the teachers in charge of operating the competences-based curriculum model. The research population was formed by higher education faculty active until 2009 that serving in public universities and have implemented the EBC model. Third stage is a questionnaire that was designed to investigate the ways in which the teacher faces his work under the competency model. The design integrates the categories and units of analysis obtained from a review of the documentary. At the fourth stage, there were conducted fieldwork and instruments that were used to obtain the required information in the study. A fifth point is the systematization of information. There were creating databases and hermeneutic units for analysis and theoretical-empirical recruitment. Finally, a diagnosis-evaluation of the situation that teaching skills in the EBC model was made, which in turn, will be contrasted with the model proposed by regulatory agencies, such as, National Association of Universities and Institutions of Higher Education (ANUIES) and "Secretaria de Educacion Publica" (SEP). Moreover, for physics teachers retake the instrument used for IESs of Tabasco, with the difference that the application was originated online at: http://tlamatiliztli.mx/fisica/

In order to confirm the sample of physics professors was made an open invitation to the universities before mentioned, which replicated it to other universities. The invitation was made to answer a questionnaire about the perception people have about the EBC [13]. The sample comprises 38 IES teachers across the country and even we received responses from Physics teachers of the Republic of Cuba.

\section{Analysis}

Since the late nineties, it begins to take shape in Mexico the idea of unifying the criteria in the curriculum of higher education level. It is in order to homogenize the credits on track to achieve international accreditation of curriculums to ensure academic mobility and the consequent approval in the training of a global citizen.

Tabasco State is located in southeastern Mexico, has not been the exception, but there are certain characteristics that make it a relevant sector of study. It is one of the states with higher educational backwardness indicators at all levels, sometimes only surpassed by Oaxaca or Chiapas.

Earlier reports of this research realize the need to take new teaching skills in higher education teachers from the inclusion of the education system to the EBC model.

Widely, IESs in Tabasco have adopted this model since 2003. This implementation translates as mandatory from a recommendation of World Bank linked to financing, which was taken up by the ANUIES and various educational programs accreditation bodies grouped in the State Commission for Higher Education Planning (COEPES) and Committees for the Evaluation of Higher Education (MES).

Empirical evidences suggest that the proposal, resulting in the design, restructure and sometimes unregulated curriculum amendments, among other things, due to the 
lack of agreement about the concept of competence, which is also reflected in the confusion of the professor meeting the demand of transforming their teaching practice.

Based on a sample obtained from the Division of Social Sciences at the Universidad Juarez Autónoma de Tabasco, which was elaborated with teachers who recently participated in the Commission for the restructuring of the curricula Bachelor of Law, History and Sociology at the EBC model; it identifies the difficulties in obtaining consensus on the particularities of the model.

The 12 teachers who participated in the study pointing out: the inaccuracies and improvisations in adaptation of the curriculum model for competition are due to the absence of effective training of designers and operators; lacking of consensus among planners and disagreements on the model.

Thus, one interviewee shares: ... When we were named as commissionaires, they gave us instructions on how to make the change by stages to EBC model, when one of the commissioners dared to question that the lack of fundamentals and the damage that this incurred to careers as law, history or medicine. They have significantly restricted their subjects for the formation of generic competencies, the authorities' response was immediate ... the teacher was removed from the grounds' commission because she's blocking out the transformation ... there, we understood that we should only obey the instructions and get out as quickly as possible of the request, (4 dsh22/06/10 interview).

Further participation points: to restructure the models: ... hire people from outside who do not know the university and its contexts, unaware of teachers experience, historically efforts, they get pay big bucks and they come to tell us how they think things should be ... then, they leave and we have to remediate all ... for them, they do always a good job and they report what they want to hear ... (interview 06/29/10 7dsh).

Some important signs, in the confrontation between the being and doing of university teachers against the competences-based model (EBC), gain importance as they become focus of the analysis on the phenomenon.

Teachers in charge of operating the new model in the $\mathrm{DACSyH}$, most (57\%) beyond the age of 50 years, are teachers who joined during the decade of the seventies and eighties as full-time teachers, with the need to address the phenomenon of massification lived in public universities, so their age in college is an average of 25 to 35 years of service. These indicators allow codifying data provided by informants in empirical work: University teachers face the need to adapt, improvise or refunding their teaching, from EBC model that has been implemented across the board in all divisions of the UJAT. This has led to the emergence hybrid styles of teaching effective or combination between traditional practices and learning-centered practices.

In this sense, the applied instrument to 37 teachers of $\mathrm{T} /$ $\mathrm{C}$, which makes up $50 \%$ of the total in this professors category assigned the Academic Division Social Sciences and Humanities demonstrates the following:
$98 \%$ do not believe in the effectiveness of the model change and they reported having experienced at least three curricular changes in the last ten years; with negative results for program arguing more often the following reasons:

They have trimmed their subjects necessary for the curriculum to incorporate general subjects for all divisions.

They have been forced the disappearance of serial subjects so that in the particular case of law students can sign up without knowing "amparo" constitutional law, in history they first see history of the revolution and then they see the history of independence.

Every time graduates are worse, they are less graduates and they have to take a specialty to end with their formation

$90 \%$ said, not clear what the competency-based model mean:

Each course instructor says something different.

There are so many types of what should be a competency that we ending confused.

So many names such as skills, abilities and attitudes that do not quite understand, which goes in the programs that I design.

The $89 \%$ of full-time teaching staff said not agree to change your learning style by a competency-based model and refers to the following reasons:

On my years of "teaching", I have filled satisfaction. My students are excellent professionals.

I have been received awards for academic excellence. Why do I need to change if I have been perfecting over the years?

I am bout to retire, I do not care reforms.

These models come and go, and it is the same, I remember the model of descriptive cards, it was the same.

Tics does not interest me, nor understand that's why I have a secretary who writes on the computer all for me youth who come with their doctorates degrees and apply the competency model are rejected by students, students want to hear experiences, to be guided by someone who has lived the profession, at the end, they come back asking us, the most experience teachers, teach the class.

They are U.S. ideas, we have always taught students to be a good lawyer, to solve problems ...now everything is renamed and they want to sell fantasy.

Yet, when asked how to face the new competences model required to operate the new curricula, $100 \%$ response being prepared and comment:

Not required much, solve problems, I've always done

I've been in all processes of change since 1965 and have always successfully adjusted because the important thing is that students go to work knowing the only new thing is the computer and these entangled boards that to me, the truth, I don't care, the time is devoted to discuss specific cases in my area that is one of the most important in the formation.

I have no clear about the new competencies, I think that neither who designed them know them, I heard them 
discussing about them; they gave an order and them countermanded it and we only changed it to go out faster.

Carry pupils to court, that's what they need to do and always we have done, this is really a competence.

They should first learn to read and we cannot help them in college. What good is put in place a program that the student will understand, discuss and think if they come without the necessary skills?

I continue with my program, the other, I just put it on the list with its theme, as the authorities want.
For physics teachers the results were analyzed by an interdisciplinary group of faculty, i.e., were not the only physics teachers that make the analysis group but also there pedagogues, teachers of humanities and mathematics teachers among others. The condensed results and the created indexes are shown below:

Questionnaire responses are diverse and cover a wide range of possible answers, which can be classified positive and negative, which is seen in the following Table:

Table 1. Answers to the questions their experience in the knowledge of competences

\begin{tabular}{|c|c|c|c|}
\hline Frequent replies & unique responses & Positive response & Negative response \\
\hline & No & & \\
Very little-Little 10 & Bad & 12 & 23 \\
Courses, Dip. Esp 4 & Hard & & \\
No difference & Good & & \\
I already know it. 42 & Design UA & & \\
Investigate on by my own 2 & Lack of understanding concept & & \\
Time in years 1.3,3,12 & Lack of Institutional support & & \\
& Lack of curriculum I don't know. & & \\
\hline
\end{tabular}

In his opinion: What is the competencies based model?

\begin{tabular}{|c|c|c|c|}
\hline Frequently Answers & unique responses & $\begin{array}{l}\text { Positive } \\
\text { response }\end{array}$ & $\begin{array}{l}\text { Negative } \\
\text { response }\end{array}$ \\
\hline $\begin{array}{c}\text { Integrator Model } 20 \text { t'is the same } 4 \text { It is not clear } 4 . \\
\text { Develop C with capacities } 3 \\
\text { Troubleshooting problems } 2 \\
\text { A active student } 2\end{array}$ & $\begin{array}{c}\text { No rejection Achieve goals not know it } \\
\text { nonsense }\end{array}$ & 29 & 10 \\
\hline
\end{tabular}

Consider that this model is more suitable for the institution? Why?

\begin{tabular}{|c|c|c|c|}
\hline Frequently answers & Unique responses & Positive response & Negative response \\
\hline $\begin{array}{c}\text { Yes } 25 \\
\text { It is integral } \\
\text { It motivates students teachers } \\
\text { It makes research arises } \\
\text { NO } 7 \\
\text { is obsolete } \\
\text { let research and entrepreneurial behind. } \\
\text { Only activities are measured } \\
\text { It is better solve problems }\end{array}$ & $\begin{array}{l}\text { I do not see the difference I don't know } \\
\text { It is early }\end{array}$ & 25 & 10 \\
\hline
\end{tabular}

What has been your experience in adaptation curriculum to model $\mathrm{C}$ ?

\begin{tabular}{|c|c|c|c|}
\hline Frequently Answers & Unique responses & Positive R & Negative R. \\
\hline None yet 12 & & \\
Design 5 & & \\
Difficult, change in Ens. 5 & Rejects Student 1 \\
Lac of information 4 & No 1 1 & 22 \\
1st place, the student 3 & & \\
The application is a slow process 3 A few 3 & & \\
It is good 2 & & \\
It is confusing 2 & & \\
It is incompetent 2 & & \\
\hline
\end{tabular}


What is the work of university teachers versus model C?

\begin{tabular}{|c|c|c|c|}
\hline Frequently Answers & Unique responses & Positive R & Negative R \\
\hline Mentoring 10 & & & \\
Upgrading 7 & & & \\
Be aware and collaborate 5 & & \\
I don't know 4 & No apply. & & \\
Evaluation and Realism 3 & Develop strategies \\
Apply and adaptation 2 & Develop of Math \\
Educate and Integral & Laboratory & & \\
Development 2 & & & \\
None 2 & & & \\
\hline
\end{tabular}

Do you believe in the effectiveness of the model change and why?

\begin{tabular}{|c|c|c|c|}
\hline Frequently Answers & Unique Replies & Positive R & Negative R \\
\hline $\begin{array}{c}\text { yes } \\
\text { Entrepreneur Student } 4 \\
\text { Satisfaction of needs } 3 \\
\text { It is commitment, } 2 \\
\text { Integral student } 2 \text { It is already on place } 2 \text { not } \\
\text { It is better in Basic and MS } 4 \\
\text { It will be tested first } 3 \text { Lack of information } 2 \\
\text { lack of comprehension } 2 \\
\text { It is a lot of work for the instructor. } 2\end{array}$ & $\begin{array}{l}\text { Homogenizes } 1 \text { will be slow } 1 \\
\text { It is better upgrade curriculum. } 1 \\
\text { Lack of agreement } 1 \\
\text { It is a opportunity to restructure } 1\end{array}$ & 16 & 20 \\
\hline
\end{tabular}

Opinion: Trend of institutions to change to competency-based model.

\begin{tabular}{|c|c|c|c|}
\hline Frequently Answers & Unique Answers & $\begin{array}{c}\text { Positive } \\
\text { R }\end{array}$ & $\begin{array}{c}\text { Negative } \\
\text { R }\end{array}$ \\
\hline $\begin{array}{l}\text { Good } 5 \text { Fad4 Do not know } 4 \\
\text { Very bad } 4 \\
\text { 3Inertia necessary Lack of commitment3 international2Mandate soon } \\
\text { starts } 2 \text { must start Basic Level } 2\end{array}$ & $\begin{array}{l}\text { It is a setback } \\
\text { It limits development and innovation It } \\
\text { creates opposition } \\
\text { It only changes the assessment } \\
\text { It was developed by research Excellent }\end{array}$ & 13 & 23 \\
\hline
\end{tabular}

How do you face the new teaching skills required to operate the new curriculum?

\begin{tabular}{|c|c|c|c|}
\hline Frequently Answers & Unique Answers & Positive R & Negative R \\
\hline With continuous learning14 & Calmly & \\
It haven't been applied No 5 & Difficult by the number of and students & 20 & 16 \\
I don't know 3 there is not time 2 & Individualized teaching & \\
With two & Without institutional commitment & & \\
Open-mind 2 & Without qualified personnel \\
Bad 2 & With educational research & \\
\hline
\end{tabular}

What are the strengths of the competency-based educational model?

\begin{tabular}{|c|c|c|c|}
\hline Frequently Answers & Unique Answers & Positive R & Negative R \\
\hline Targets and skills that it develops 7 active Student 6 & & \\
Changing mindsets 6 & & \\
I don't know 5 & It is for beginners & 29 & 14 \\
I don't identify it 5 & There is not difference & \\
Generic evaluation and skills 3 & & \\
Realism and usage of TIC 3 & & \\
Attitudes and values 2 & & \\
Personalized teaching 2 & & \\
None 2 & & \\
\hline
\end{tabular}


What are the weaknesses of competency-based education model?

\begin{tabular}{|c|c|c|c|}
\hline Frequently Answers & Unique Answers & Positive R & Negative $\mathrm{R}$ \\
\hline $\begin{array}{c}\text { I don't know } 6 \\
\text { Resistance to change } 5 \\
\text { I don't not know } 5 \\
\text { Lack of communication between Education's actors } 3 \\
\text { Teachers do not understand } 3 \\
\text { All } 2 \\
\text { It is imposed. } 2 \\
\text { It is not necessary in ES } 2 \\
\text { Language not clear } 2 \\
\text { It does not say how to develop skills and evaluate } 2\end{array}$ & $\begin{array}{c}\text { There is not difference } \\
\text { Need of good teachers } \\
\text { Lack of time } \\
\text { It is receding, In some countries, it have failed } \\
\text { It is not covered } \\
\text { Educate Plans } \\
\text { Teachers } \\
\text { No study of Science } \\
\text { Ambiguous Definition } \\
\text { Number of Students }\end{array}$ & 17 & 24 \\
\hline
\end{tabular}

What is observed in response tables is that two thirds do not have experience in the learning model (1), the model itself is quite accepted (2) but not as a trend (7).

It is good, right (3), some curricula have already been restructured (4), it is considered very positive for Teachers (5).

There are some doubt that the change is effective (6), but it is considered to be a good adaptation effort (8).

The model has many strengths and weaknesses that are implemented by itself.

\section{Conclusions}

The presented project progress allows us to draw some preliminary conclusions:

Based on the review of available literature on EBC model it can be said that there is not a theoretical methodological proposition for its definition and the existing have not reached a consensus in our country, which largely explains the disagreements of the design and operation of the educational curricula of IES which have moved into this mode.

EBC model is a proposal that emerges labor market, from there; it is defined competencies that become teaching goals. This new dynamic means that the University must have an active and effective role in promoting closer ties with production structures, which it is not easy because the different motivations and objectives that constitute their agendas. Cuban (1992) argues that the difference between the two bodies is mediated by a cultural problem and explains it in relation to what they feel like a threat:

.... the culture of the university is to value reflection, analysis, scientific research, while the company evaluates the application of knowledge to practical situations and experiences based on knowledge that is applicable to their processes.

Curriculum design EBC model is done by "order" because it's pointing to the formation of professional "mode" doomed to meet the human capital requirements of companies and employers.

EBC model requires specific competencies for its operation. But teachers who are responsible for its operation, coming from rigid structures, highly professionalizing teachers that understand teaching as an subjective, individual and personal exercise that depends of the experience for its completion.

University teachers have responded to the requirements model with attitudes of resistance, considering the effectiveness of their practices, or denying their involvement in it, by a by open refusal to its participation; others have adapted to the new conditions with a positive attitude, open to change. However, the study begins to outline that teachers with more seniority and teaching experience reject or resist change for reasons to discredit and lack of agreement with the model.

When the EBC model is focusing on performance, it rejects aspects like teaching experience and the tacit knowledge that the professional requires. It is clear that teachers have made interesting proposals in reflective practice, known as Schon (1998) in his book The Reflective Professional: how professionals think when they act, hence the importance of recovering the way to deal with change to suggest models for IES teachers in Mexico.

Physics teachers seem to be more open, but are polarized on their view of the competency model. An interesting situation is that although many comments on the model many of them indicate a lack of knowledge about the model.

An interesting situation is that teachers whose knowledge of the EBC model is better manifested their inability to give a diagnosis of the model at this time, based on the thought that they need to see several generations of students to assess the success or failure.

\section{REFERENCES}

[1] Beneitone, P. Reflexiones y perspectivas de la educación superior en América Latina, Informe Final Proyecto Tuning para América Latina 2004-2007. Bilbao, Publicaciones de la Universidad de Deusto, 2007.

[2] Cañas, A., Martín-Díaz, M. y Nieto, J. Competencia en el conocimiento y la interacción con el mundo físico. Madrid, Alianza Editorial, 2007.

[3] Universidad de Deusto. Reference Points for the Design and 
Delivery of Degree Programmes in PHYSICS. Bilbao, Publicaciones de la Universidad de Deusto, 2008.

[4] IPN. Materiales para la reforma Libro 1: Un Nuevo modelo educativo para el IPN. Instituto Politécnico Nacional, 2004.

[5] Ramírez, M. \& Olvera, M. Formación de profesores de bachillerato en competencias específicas de la física utilizando cursos intersemestrales en el IPN. Lat. Am. J. Phys. Educ. Vol. 6, No. 2, June 2012.

[6] Aguilera, J. \& Cuevas, G. Adaptación de la Metodología Tuning para el levantamiento del perfil de egreso de los alumnos de Bachillerato de la Universidad de los Andes. Calidad en la Educación, No. 34, julio 2011, pp. 219-230.

[7] Romero, L., Hernández, A., \& Gracida, N. Competencias docentes en profesores de las IES de Tabasco que han implementado el modelo curricular basado en competencias (EBC). Memorias del $\mathrm{V}$ Congreso Internacional de Innovación educativa, CFIE-IPN, Mérida, 2010.

[8] Ramírez, M. Perception on Model of Competences in Physics Teaching. AAPT Sumer Meeting 2011, Portland, USA, pp.
$107,2011$.

[9] Ramírez, M. Differences between social science teachers and physics teachers about belifs of competencies model in Mexico. World Conference on Physics Education, Istambul, Turkey, 2012, pp. 376. 2012.

[10] Ramírez, M. \& Chávez, E. The Tuning Project in Physics Area in Mexico. AAPT Winter Meeting 2012, Ontario, USA, pp. 66. 2012.

[11] Pérez-Trejo, L., Méndez-Sánchez, A., Ramírez, M., Olvera, M., González, A. Persepción de profesores de física y matemáticas sobre el modelo educativo basado en competencias. Lat. Am. J. Phys. Edu. Vol. 6, N. 4, pp. 614-617, 2012.

[12] Hernández, R., Fernández-Collado, C. \& Baptista, P. Metodología de la Innvestigación. México, D.F., McGraw Hill, 2006.

[13] Ramírez, M. Perception of Physics Teachers in Mexico about Competences Model. US-China Educational Review A, Vol.3, No. 7, 540-545, 2013. 